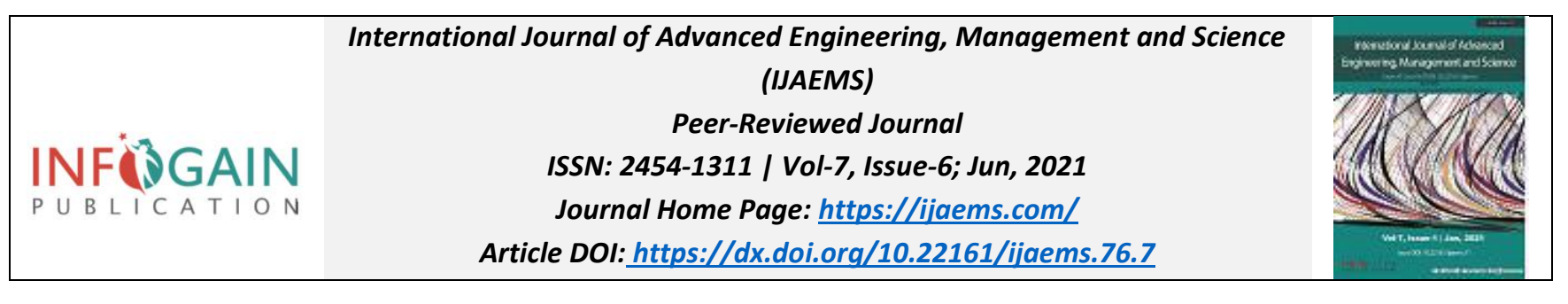

\title{
Viability of Village Dressmaking as an Industry Amidst an era of Ready-To-Wear Garments
}

\author{
Al John P. Marcelino, Oliver B. Gabay, Jennifer G. Gazzingan, Mark Joseph C.Factor, \\ Toby P. Veneracion, Jennifer G. Fronda
}

Master in Business Administration, Graduate School, Nueva Ecija University of Science and Technology, Philippines

Received: 04 Apr 2021; Received in revised form: 22 May 2021; Accepted: 04 Jun 2021; Available online: 14 Jun 2021

\begin{abstract}
This study evaluated the dressmaking livelihood project of the Municipality of Santa Rosa, Nueva Ecija. Using descriptive research design with 15 purposively selected beneficiaries as the respondents, the study revealed that the dressmaking livelihood program was one of the higher platforms to assist the people to have an income and lessened the unemployment rate in the community. However, the livelihood project was not fully effective due to a lack of coordination and improper implementation of the program. Most of the beneficiaries of the dressmaking program were female since in the Philippine culture the stitching was seen as a "woman's traditional job".
\end{abstract}

Keywords—dressmaking, employment, income, livelihood projects, viability.

\section{INTRODUCTION}

Livelihood program is one of the best alternatives source of income to support the needs of the Filipino families. Due to increasing unemployment one of the main reasons is unavailability of job provided, some causes are economic recession and over population. Lack of investors and businesses that can provide good jobs for the Filipino people is one of the main reasons of unemployment here in the Philippines.

Supporting your basic needs is not an easy thing without the permanent sources of income. People need a source of income to support their everyday living. Municipality, where there is a potential growth of the business was in need of guidance for the enhancement of their livelihood. The livelihood program of the government will be the start up of the business to help the community while providing also an opportunity to others in terms of employment.

Santa Rosa is a first class municipality in the province of Nueva Ecija, Philippines. The town primarily depends in rice cultivation, vegetable production, commercial fishery, and tricycle sidecar fabrication [1]. Just recently, the townstarted realizing its development potential in the production of ready-to-wear and made-to-measure dresses for all ages and for any gender. In the western part of the

This article can be downloaded from here: www.ijaems.com town going to Tarlac, one can see there are lines of shops where busy people are sewing different kinds of dresses and other fabric related products [2].

"Community-based Training for Enterprise development Program of TESDA is primarily addressed to the poor and marginal groups, those who cannot access, or are not accessible by formal training provisions. They have low skills, limited management abilities, and have few economic options. They have no access to capital - most of them are unqualified for formal credit programs. The program goes further than just mere skills training provision. It is purposively designed to catalyze the creation of livelihood enterprises that shall be implemented by the trainees, immediately after the training"[3]."Likewise, it is designed to assist partner agencies such as LGUs, NGOs, people organizations and other agencies organizations with mission to help the poor get into productive undertakings to help themselves and their community"[4].

Livelihood assistance given by the government sector will be the chance to improve the living of the people. The program like this helps the beneficiaries, while the beneficiaries will create a job opportunity to other people within the area. Moreover, this kind of program in the area will be developed and eventually be acknowledged.

62 
Livelihood refers to the assets and resources possessed by individuals (both material and social) and the activities carried out to generate resources for means of living. Livelihood is "adequate stocks and flows of food and cash to meet basic needs. Thus a livelihood is understood broadly as people and their capabilities, activities, assets, both social (claims and access) and material (resources and stores) and gains from what they do[4].

Provision of livelihood enhancement program is one of the most important things to the communityespecially to those who have a big potential to establish businesses like municipality. The program will boost the industry of and also create an opportunity to job seekers to lessen the unemployment rate in the municipality.Targeted training programs have the potential to address the problem of low skills among the poor workers, especially the young ones. expanded if proven to be cost-effective [5]. The study aimed to assess the livelihood enhancement of the residents of Santa Rosa, Nueva Ecija. To identify the constraints in programs implementation. This study is attempted to evaluate the collaboration of the Municipality dressmaking; one of the sources of income in the dressmaking, learning a lot, which they used to strategized Such programs should be developed on a pilot basis and

of Santa Rosa, Nueva Ecija under the Philippine Employment Service Office (PESO) and Technical Education and Skills Development Authority (TESDA) in promoting livelihood activities in the municipality of Santa Rosa in the Province of Nueva Ecija.

\section{METHODOLOGY}

The respondents of the study were the fifteen beneficiaries of the Dressmaking Project by the Municipality of Santa Rosa. The descriptive research design was utilized in this study. "The descriptive research design helps provide answers to the questions of who, what, when, where, and how associated with a particular research problem; a descriptive study cannot conclusively ascertain answers to why. Descriptive research is used to obtain information concerning the current status of the phenomena and to describe "what exists" with respect to variables or conditions in a situation"[6]. The survey questionnaire was the main instrument used by the researchers in conducting this study.

\section{RESULTS AND DISCUSSION}

1.Profile of Respondents

Table 1. Demographic Profile

\begin{tabular}{|c|c|c|c|}
\hline & Profile & Frequency & Percentage \\
\hline AGE & $18-28$ & 3 & $20 \%$ \\
\hline & $29-39$ & 5 & $33.33 \%$ \\
\hline & $40-49$ & 1 & $6.67 \%$ \\
\hline & $50-59$ & 5 & $33.33 \%$ \\
\hline Gender & 56 and above & 1 & $6.67 \%$ \\
\hline & Total & 15 & $100.00 \%$ \\
\hline & Male & 0 & $0.00 \%$ \\
\hline & Female & 15 & $100.00 \%$ \\
\hline & Total & 15 & $100.00 \%$ \\
\hline & Single & 1 & $6.67 \%$ \\
\hline & Married & 14 & $9333.00 \%$ \\
\hline & Separated & 0 & $0.00 \%$ \\
\hline & Widowed & 0 & $0.00 \%$ \\
\hline & Total & 15 & $100.00 \%$ \\
\hline & Elementary & 9 & $60.00 \%$ \\
\hline & High School & 4 & $26.67 \%$ \\
\hline & College Undergraduate & 2 & $13.33 \%$ \\
\hline & Total & 15 & $100.00 \%$ \\
\hline
\end{tabular}

This article can be downloaded from here: www.ijaems.com 
Table 1 shows the demographic profile of the respondents. Based on the gathered data, the majority of the beneficiaries were married, aged 29-39 and 50-59, they were all female, and elementary graduates. "Bryner indicated the trend of employing women in positions as operatives was likely because sewing was seen as "woman's traditional job"[8].

Table 2.Source of Income Before the awarded of Livelihood Program

\begin{tabular}{|l|c|c|}
\hline Source of Income & Frequency & Percentage \\
\hline Employees & 0 & $0 \%$ \\
\hline Sari-sari Store Owner & 1 & $0 \%$ \\
\hline Farmers & 0 & 13.33 \\
\hline Vendor & 2 & $73.33 \%$ \\
\hline None & 10 & $6.67 \%$ \\
\hline Live Chicken Dealer & 1 & $100 \%$ \\
\hline TOTAL & 15 & $07 \%$ \\
\hline
\end{tabular}

It can be viewed from the table that the majority of the benificiaries have no source of income with $73.33 \%$.It was indicated that that the livelihood program is beneficial to the unemployed individuals of the municipality of Santa Rosa in Nueva Ecija.

Table 3. Monthly Income

\begin{tabular}{|l|l|r|}
\hline Monthly Income & Frequency & Percentage \\
\hline Monthly Income before the project was awarded & & $80 \%$ \\
\hline 5,000 and below & 12 & $13.33 \%$ \\
\hline $5,001-10,000$ & 2 & $6.67 \%$ \\
\hline $10,001-15,000$ & 1 & $100.00 \%$ \\
\hline Total & 15 & $33.33 \%$ \\
\hline Monthly Income after the project was awarded & & $6.67 \%$ \\
\hline 5,000 and below & 5 & $60 \%$ \\
\hline $5,001-10,000$ & 1 & $100.00 \%$ \\
\hline $10,001-15,000$ & 9 & 15 \\
\hline Total & 15 & \\
\hline
\end{tabular}

Based on the gathered information, $80 \%$ of the monthly income of the beneficiaries before the project was awarded was below 5,000 pesos. After the project was awarded to them the monthly income of the majority was 10,001-15,000 pesos or 9 out 15 respondents while $33.33 \%$ or 5out of 15 answered below 5,000 pesos. Based on the data eight (8) of the respondents increased their income, while the seven(7) were not, since the tool kit, which is their primary need to start in generating their income was not distributed. While the 7 respondents which improved their monthly income, since they have already sewing machines.

\section{Challenges Encountered by the Beneficiaries}

Table 4. Challenges Encountered by the Beneficiaries

\begin{tabular}{|l|c|c|}
\hline Problems & Frequency & Percentage \\
\hline Lack of Expertise & 1 & $6.67 \%$ \\
\hline
\end{tabular}




\begin{tabular}{|l|c|c|}
\hline Selling of the products & 8 & $53.33 \%$ \\
\hline Insufficient Machinery and Equipment & 6 & $40 \%$ \\
\hline TOTAL & 15 & $100 \%$ \\
\hline
\end{tabular}

As can be gleaned from Table 2, most of the challenges encountered [8] by the beneficiaries were selling of the products $(53.33 \%)$, and insufficiency of machinery and equipment (40\%). As mentioned, the machine or the sewing kit were still not provided by the sector-in-charge of the projects. It is almost a yearsince they finished the livelihood training. As per the respondents, lack of support was extended by the Municipality of Santa Rosa to the respondents in selling their products.

\section{Training and Assistance provided by the Municipality of Santa Rosa}

The beneficiaries' training was provided by the Technical Education And Skills Development Authority (TESDA) and received their National Certificate II (NCII) Dressmaking after the completion of the training, they all received financial assistance amounting to Php 2,000.00 for their allowance. Based on the survey questionnaire the Municipality of Santa Rosa, Nueva Ecija lackof assistance to the beneficiaries during the pandemic.

\section{CONCLUSION AND RECOMMENDATION}

Mostly females were beneficiaries of the Dressmaking Livelihood Program in the Municipality of Sta. Rosa. The majority of them were elementary graduates and have a monthly income of below 5,000 pesos. The livelihood program is not fully effective due to lack of coordination and improper implementation of the program. The livelihood program is one of all the higher platforms that assist the people to get income and lessened the the unemployment rate in Sta. Rosa. In the light of the findings and the conclusion made, the researchers highly recommend the following: The beneficiaries must be provided with the capability training to familiarize them with more effective marketing and selling strategies. The municipality that provided a livelihood program must assess their livelihood industry, and focus on the enhancement rather than provide a program without a definite plan particularly during pandemic. In that case, the project will be more feasible. The program like this must have proper supervision and training to address the needs of the beneficiaries and to provide the training that will help them improve [10] and be more competitive.

\section{REFERENCES}

[1] Santa Rosa, Municipal Health Office

https://santarosamunicipalhealthoffice.wordpress.com/about/

[2] Jelaica S. Alarilla (2016), Basic Economics for Dressmaking/Tailoring

https://www.academia.edu/30680121/BASIC_ECONOMICS_for_DRESSMAKERS_TAILORS_A_Community_B ased_Alternative_Learning_System_ALS_Module

[3] Technological Education and Skills Development Authority, Provincial Training Center

https://ptcpangasinan.wixsite.com/education

[4] Technological Education and Skills Development Authority, Community Based Programs.

https://www.tesda.gov.ph/About/TESDA/37

[5] Livelihood Promotion (2016), Livelihood a Bird's Eye View

https://www.spadeglobal.in/what-we-do/livelihood-promotion/

[6]Anatas, et al (1999), Flexible Methods:Descriptive Research

https://libguides.usc.edu/writingguide/researchdesigns

This article can be downloaded from here: www.ijaems.com 
[7] Bryner, Dressmaking and Millinery; The Garment Trades, page 19, 49.

[8] Abelardo, L., Lomboy, M., Lopez, C., Balaria, F., \& Subia, G. (2019). Challenges Encountered by the National High School Teachers in Doing Action Research. International Journal of English, Literature and Social Science (IJELS), Vol-4, Issue-4, Jul - Aug 2019 https://dx.doi.org/10.22161/ijels.4418 ISSN:2456-7620.

[9] Mina, J., Subia, G. \& Ermita, P. (2020). Value Chain Analysis of Slipper Industry in the Footwear Capital of the North. International Journal of Supply Chain Management. Vol.9, No.5, 178-183.

[10] Garcia, Mary Grace \&Subia, Gener (2019). High school athletes: Their motivation, study habits,self-discipline and academic performance.International Journal of Physical Education, Sports and Health 2019; 6(1): 86-90 